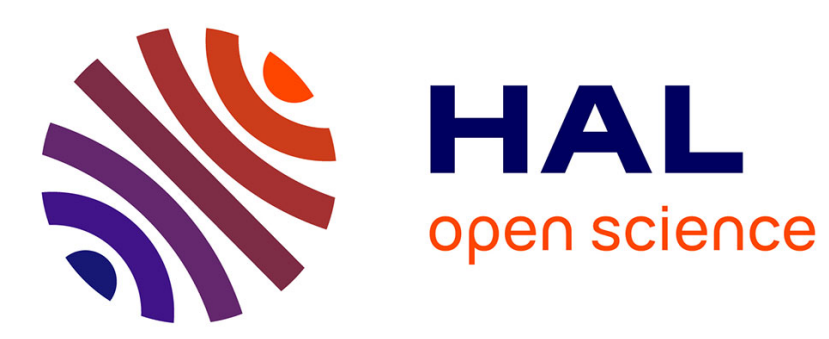

\title{
Pioneers of European Integration
}

Adrian Favell, Ettore Recchi

\section{To cite this version:}

Adrian Favell, Ettore Recchi. Pioneers of European Integration: an introduction. Pioneers of European Integration: Citizenship and Mobility in the EU, Edward Elgar, pp.1-25, 2009. hal-01071327

\section{HAL Id: hal-01071327 \\ https://hal-sciencespo.archives-ouvertes.fr/hal-01071327}

Submitted on 22 Dec 2014

HAL is a multi-disciplinary open access archive for the deposit and dissemination of scientific research documents, whether they are published or not. The documents may come from teaching and research institutions in France or abroad, or from public or private research centers.
L'archive ouverte pluridisciplinaire HAL, est destinée au dépôt et à la diffusion de documents scientifiques de niveau recherche, publiés ou non, émanant des établissements d'enseignement et de recherche français ou étrangers, des laboratoires publics ou privés. 


\title{
1. Pioneers of European integration: an introduction
}

\author{
Adrian Favell and Ettore Recchi
}

\section{INTEGRATING EUROPE 'FROM BELOW': THE ROLE OF FREE MOVEMENT}

The European Union stands as a unique economic, political, legal and social experiment in transnational regional integration. The world we live in may still be one primarily organized by and for territorial nation states, but if one empirical example is to be sought of how a post-national or cosmopolitan polity and society might be built, the EU is the only actually existing institutional example. Built on a regional territorial logic, its complex structures are also the best guide to the way a progressive and governable political order might be constructed from the economic free-for-all of globalisation. In no other part of the world have sovereign nation states bonded together to voluntarily relinquish large aspects of their sovereign control of economy and polity to a set of common supranational institutions. And in no other part of the world have such institutions created a form of post-national citizenship within a transnational regional political order.

Arguably the most fundamental part of the traditional nation state's claim to sovereignty is its claim of territorial jurisdiction over the member citizens that live within its borders (Torpey 2000). Yet at the heart of the European Union lies the principle of free movement: of the capital, goods and services that oil the wheels of international trade and business, but also of persons who, within its realm, now have the right to move, travel, study-work, settle and retire anywhere within its member states. EU citizens can move and demand equal treatment to that of all nationals of the same territory in every dimension of work and public life. This revolutionary principle has existed within European law since the Treaty of Rome in 1957; with the expansion of the EU to 25 members in 2004 and 2007, it now extends the notion of European citizenship - and potentially of a single European society - all the way from the Atlantic to the Urals and the borders of the Black Sea (European Commission 2002). 
Curiously, though, scholars have been slow to explore the social effects of European integration. EU studies are dominated by policy and legal studies, the sweep of intergovernmental and functionalist theories, macroeconomic models of monetary union and the detail of diplomatic history. There is much less work on the consequences - or, indeed, the sources - of the integration process, in the lives and activities of the almost 500 million citizens who now make up this extraordinary experiment (Favell 2006a). Freedom of movement, in fact, is the core right of European citizenship: it is the right most often cited by Europeans as the single most valuable benefit of that membership (European Commission 2006). ${ }^{1}$ As a social phenomenon, then, cross-border movement within Europe - the spatial mobility of European citizens - ought to be seen as one of the key dimensions of European integration. Indeed, when thought of more broadly, it is a key indicator of the very possibility of post-national global or regional integration at the individual, human level.

Many European citizens are using these rights to move to other countries of the EU. Large numbers of southern workers used newly minted freedom of movement accords in the 1950s and 1960s to migrate north to the expanding industrial economies of the north. This worker-based migration still continues in modified form. Now, though, many other categories of mover are also visible, particularly among the citizens of the EU15 member states, who have enjoyed these rights for decades. From 1987 to 2005, 1.4 million European students benefited from Erasmus and Socrates programmes to spend up to two years at a foreign university. Likewise, 12000 advanced researchers and scientists have received support to move and work abroad. ${ }^{2}$ Major cities like London, Amsterdam, Paris, Milan, Barcelona and Munich have become dynamic hubs of the intra-European mobility of young workers, who choose to look for work on an individual basis. These possibilities have particularly impacted the life and career choices of provincial and peripheral citizens of the EU frustrated with their national opportunities, and of young women or those with unconventional lifestyles, such as homosexuals, who have used international mobility as an avenue to self-liberation. Furthermore, an ever-increasing number of retirees and near-to-retirement citizens from the north of Europe are deciding to pack up and buy a house in the south. There is, as Russell King calls it (2002), a 'new map of European migration'.

All of these potential avenues to European freedom are now, or will be at some point, accessed by new European citizens from new member states since the enlargements of 2004 and 2007 (Favell 2008b). These are, simply put, extraordinary movements. For Europe is a continent better known for low levels of cross-national, even cross-regional movement, and very high expectations of sedentary regional and national identification.

Ps

stati

freer

intr:

stat

the:

200:

Stat

is th:

free

Eur

whi

orig

call

vas1

thei

F.

less.

tho:

In

$\operatorname{arcl}$

are

face

to $\mathrm{k}$

out

cos:

fail

alsc

bei]

tive

mo

prc

Soc

the

atir

$(\mathrm{Fi}$

of

Eu.

dir 
zial effects and legal es, macroic history. urces - of 00 million :11 2006a). tizenship: : valuable $s$ a social he spatial zy dimenroadly, it r regional

her counly minted ; north to ed migraategories he EU15 I 1987 to Socrates Likewise, to move s, Milan, suropean Idividual id career ted with I unconnational Icreasing lorth of ere is, as

ir will be ier states 2 , simply $r$ known ind very I.
Perplexingly, these on-the-ground social shifts are not always seen in the statistics. These sometimes frame the story in a different way. Debate about freedom of movement of workers focuses on the surprisingly low levels of intra-state resettlement, particularly when compared to the dynamic crossstate and regional movements of Americans (European Foundation for the Improvement of Living and Working Conditions 2006; see also Recchi 2005 and 2006). The USA remains a potent federal model of how a 'United States of Europe' might look, and its economic dynamism in these terms is the inspiration for the EU's own adherence to notions of mobility and free movement. In fact, when looking at statistics, fewer than one in 50 Europeans lives outside their nation of origin. Around 4 per cent meanwhile have some experience of living and working outside their country of origin. These are figures that suggest the population of 'EU movers', as we call them, is a marginal, if not statistically insignificant counterpoint to the vast majority of 'EU stayers', those people who stay living and working in their own country.

However, the symbolic importance of the moving EU population is not lessened by the numbers. Movement and mobility have huge effects on those involved, both those who move and those who encounter movers. In each and every one of these lives, the hopes and aspirations of the architects of the European integration process are inscribed. EU movers are the prototypical 'Highly Europeanized Citizens'. They are the human face of European integration, from whom we might learn what it means to be a European. Their lives and experiences are the best guide to finding out how easy it is to shift one's identity or horizon to a post-national or cosmopolitan level, and of the practical benefits, insights, barriers and failings of a life lived outside the place where you historically belong (see also Favell 2008a).

Pioneers of European Integration sets out to explore the new Europe being built by these individuals. It represents the first systematic, quantitative attempt to study the impact and consequences of European freedom of movement of persons. Drawing on a multi-headed international research project, with a large scale original survey - the European Internal Movers Social Survey (EIMSS) - at its heart, it presents findings and evidence on all the big questions posed by the movement of European citizens within a relatively static continent. The project, funded by the European Commission (Fifth Framework Programme of research, 2003-06) was titled Pioneers of European Integration 'From Below': Mobility and the Emergence of European Identity Among National and Foreign Citizens in the EU, and was directed by Ettore Recchi. It was best known by its acronym PIONEUR. ${ }^{3}$

EIMSS surveyed movers from the five most populous EU15 member states (Germans, French, British, Italians and Spanish) to the five most 
populous EU15 member states (Germany, France, Britain, Italy and stati Spain). It was conducted in 2004. One of the largest-ever comparative sour migrant surveys, EIMSS surveyed a total of 5000 European citizens who settled abroad in EU member states after 1973. ${ }^{4}$ The questions were designed to allow for the highest possible comparability with the European Social Survey (ESS) and Eurobarometer (EB), in order to highlight the specificities of EU movers versus EU stayers. For more technical information, we include a methodological appendix at the end of the book (Appendix A).

EIMSS permits a vast range of questions to be asked. Who are the EU movers? Where do they come from regionally and socially, and where do they go? How well do they acclimatize to their new settings, and how do they self-select? Why did they move? How do their values, orientations and identifications compare to the EU stayers? What are the consequences of their political participation and media consumption as cross-national European citizens? Are these migrants somehow building a new European identity - for themselves, if not for the continent? And how do movers from the pre-2004 EU15 member states compare to the new movers that we will see taking up these rights from the A12 member states who joined the EU in 2004 and 2007?

If nothing else, the backgrounds, experiences, social trajectories, careers and (perhaps) transformations of these prototypical EU movers will contrast sharply with the more stable and familiar patterns of class, values and participation of the majority European population of EU stayers, who remain spatially attached to their nations, regions and localities. EU movers' behaviour and experiences are also a good indicator of new forms of mobility that deviate from the norms of international and regional migration. The subject may also offer the key to new thinking in social mobility research, if spatial mobility in Europe is linked - as can be hypothesized - to upward social mobility. Researchers have struggled to transcend the methodological nationalism that is inherent in social stratification tied to comparison of social mobility within national societies (Breen and Rottman 1998). Cross-national spatial mobility has been recognized as a key area for testing new avenues of social mobility potentially linked to global and regional economic processes (Breen 2004), and EIMSS allows us to do this.

Pioneers of European Integration answers these questions with systematic evidence and analysis. In the remainder of this introduction, we provide some background to the project. First, we sketch the history of free movement rights in terms of European law and its evolution. Second, we consider briefly the underlying economic and political rationale for their expansion. Then, in the third section, we offer an overview of existing

$\mathrm{emF}$ 
Italy and mparative n citizens ions were European hlight the cal inforthe book

:e the EU where do d how do entations equences -national Juropean o movers ivers that ho joined

$\mathrm{s}$, careers will conis, values I stayers, ocalities. icator of onal and inking in - as can itruggled in social al sociehas been $y$ poten104), and

rith systion, we istory of Second, nale for existing statistics on migration within the EU, drawing on various international sources. Finally, there is an introduction to the chapter-by-chapter empirical analyses that follow in the book.

\section{A SHORT HISTORY OF FREE MOVEMENT RIGHTS}

The origins of free movement rights in the European Union date back to the early 1950s. Free movement was in fact first introduced by the pioneer supranational organisation of shared economic interests, the European Coal and Steel Community (ECSC) formed in 1951, to facilitate specialised workforce recruitment across national borders. Among the six founding states of the Community (Germany, France, Belgium, the Netherlands, Luxembourg and Italy), Italy was particularly keen to support this goal, in order to lower domestic unemployment and underemployment, as well as to improve the living conditions of nationals who had already migrated abroad (Romero 1993; on the development of free movement rights, see also Wiener 1998; Maas 2007).

The ECSC Treaty limited free movement to 'workers who are nationals of member states and have recognized qualifications in a coalmining or steelmaking occupation' (article 69), but the right of free movement was generalized in the founding Treaty of the European Economic Community signed in Rome in 1957. Article 48 of this Treaty affirmed the right to accept offers of employment made in another member state and to move freely within the Community, as well as to reside and remain in another member state after having been employed. In its original version, however, the Treaty limited the right to move to 'workers' rather than 'citizens'. At this stage, Community law openly treated migrants as production factors rather than persons tout court, in line with the market-oriented view of European integration. While bilateral agreements between national governments within Western Europe had been established soon after World War II, and extended later to more peripheral countries such as Portugal and Yugoslavia, the EEC treaty built a more solid legal framework for an intra-European mass migration system of its age. In short, free movement met the interests of both would-be foreign workers in Italy and potential employers in Germany, Benelux and France.

However, the legal enactment of free movement proceeded at a slow and discontinuous pace (for more detail on the EU's legal evolution and jurisprudence, see especially O'Leary 1996; Guild 1999; White 2004; De Bruycker 2006). For more than a decade, in spite of the Rome treaty, citizens of EEC member states who intended to work in a different member state continued to be subject to national immigration laws. They had 
to apply for work and residence permits, which could be discretionarily denied - just like any other immigrants. According to article 49 of the Treaty, free movement was a fully intergovernmental policy left to decisions taken in the Council of Ministers. Central and Northern European EEC member states resisted the interference of supranational regulations on their sovereign power to control aliens. More specifically, in these countries it was often argued that free movement would have given some competitive advantage to Italians over other southern European migrants, making them less disposable as guest workers.

The real implementation of free movement was thus postponed to 1968 , when Council Regulation 1612/68 and Council Directive 68/360 abolished movement and residence restrictions on member state workers and their families in the entire EEC territory. On the one hand, Regulation 1612/68 made illegal all nationality-based discrimination between workers of member states, in terms of work conditions, salary and unemployment benefits. Furthermore, it established the foreign workers' right to the same social and tax benefits as national workers, including access to training in vocational schools and housing benefits (where existing). Family members of foreign workers were entitled to reside with them and to be allowed access to any kind of employment in the host country. On the other hand, Directive 68/360 reduced the bureaucratic formalities of moving within the EU considerably, recognising the workers' and their families' rights to enter a different member state by simply showing an identity card or valid passport, without being forced to obtain a visa. Migrants within the EU were also entitled to a residence permit, with a validity of at least five years and an automatic renewal, by presenting an employment certificate. In addition, permanent residency thereafter in the host country was also guaranteed, as the residence permit could not be withdrawn in the case of involuntary unemployment. Neither could being unemployed justify expulsion.

The 1968 provisions thus represented a turning point. They ended the transitional regime set by article 49 of the Treaty, and created the conditions for a full exercise of free movement rights. In the following decades, admission, residence and equal treatment of foreign residents from other member states were dealt with by a vast secondary legislation. Community law and the European Court of Justice (ECJ) have increasingly widened the matter and scope of the right to free movement originally contained in the Treaty. In particular, since the 1970s, the ECJ has played a key role in widening the scope of free movement. It has systematically shifted its focus from the free movement of workers to the free movement of persons - that is, movement independent of an individual's capacity as an economic actor. Following high-profile cases brought by citizens, the

Cou

citiz

to $e_{1}$

mar

tion

tion

the

nati

in a

acti

con

sent

thei

20 I

inte

and

in

ext

stur

are

the

twe

anc

suf.

sys

adr

gre

EL

pla

19 !

$\mathrm{Tr}$

pre

$\mathrm{Cc}$

na

$\mathrm{Pa}$

ali

EI

$\mathrm{me}$

on

$\mathrm{mr}$ 
etionarily 49 of the to decisEuropean gulations in these ven some nigrants,

1 to 1968 , ibolished and their 1 1612/68 irkers of sloyment the same aining in members allowed ter hand, $\mathrm{g}$ within ss' rights card or ithin the least five rtificate. was also the case $\mathrm{d}$ justify

Ided the : conditJecades, $\mathrm{m}$ other .munity widened intained d a key ' shifted ment of acity as ens, the
Court was able to broaden interpretation of the Treaty, emphasising the citizenship dimension of free movement. According to the ECJ, the right to equal treatment implies a fully-fledged integration, not only in the job market, but in the whole of society, including social, cultural and educational aspects of workers' and families' lives. With the decisive contribution of the ECJ jurisprudence, laws on free movement were extended in the 1970s to foreign self-employed workers, and in the 1980s to foreign EU nationals who take up a paid apprenticeship, those who enter university in a member state different from their own after having taken up a job activity, and to seasonal workers. It can also be noted, though, that the controversial position of posted workers - workers who are temporarily sent to another member state to perform services there and who return to their country of origin after completion of their work - was clarified only 20 years later, with Council Directive 96/71.

The Single European Act of 1986 aimed at creating an 'area without internal frontiers in which the free movement of goods, persons, services and capital is ensured'. A logical consequence of this was the step taken in 1990, when freedom of movement and residence was now explicitly extended to non-economically active categories (as well as their families): students, pensioners and the unemployed. The legal bases of these changes are to be found in Directives 90/364, 90/365 and 90/366 (this last was then replaced by Directive 93/96). Such arrangements are still subject to two conditions from which workers are exempted: students, pensioners and the unemployed must have sickness insurance, and they must have sufficient resources to avoid becoming a burden on the national health systems or social assistance of the host member state. Another collateral advance was the adoption of the Schengen system, which took place progressively in the 1980 s and 1990 s, to eliminate passport controls between EU national borders.

Symbolically, however, the most spectacular step in the process took place with the Treaty on the European Union, signed in Maastricht in 1992, and which entered into force on 1 November 1993. The Maastricht Treaty introduced citizenship of the European Union to "reinforce the protection of the rights and interests of the nationals of its member states'. Concretely, EU citizenship consists of a set of rights allowing all European nationals to vote and stand as candidates in elections of the European Parliament in the member state they reside in, regardless of their nationality; to submit petitions to the European Parliament and appeal to the EU Ombudsman; to be protected by the consular authorities of another member state in third countries that lack diplomatic representation of one's state; and to move and reside freely in the territory of any of the EU member states. 
The first three provisions are small in scope compared to the last. For the ordinary EU citizen, access to diplomatic protection in third countries is an extremely unusual event and petitions to the European Parliament or the Ombudsman look like quite remote options. Meanwhile, to vote as a foreign resident for the European Parliament has proven of little political relevance, with high abstention rates. Local voting rights are more widely used. But it is the rights to free movement and settlement in the entire EU territory that form the most potent cornerstone of EU citizenship.

In more recent years, Commission Directive 2004/38 consolidated the residence rights of EU movers throughout the Union territory. This Directive not only unifies pre-existing scattered legislation on free movement, but also incorporates some key tenets of the jurisprudence of the ECJ. In particular, it acknowledges the right to permanent residence of EU citizens after five years of stay in any other member state without additional formalities (such as a carte de séjour), as well as the host state's responsibility for the social welfare of movers. Overall, this Directive defines three categories of mobile EU citizens - short-term movers (less than three months), long-term (between three months and five years), and permanent (over five years) - whose social welfare rights in the host country are correspondingly graduated.

Apparently the only remaining limits to the universalisation of free movement rights in the EU are the ability to vote in the general elections of the host country - which remains the ultimate seal of acquiring national citizenship; the unconditional access to state-based social benefits - inactive movers still need to have their own sickness insurance; and (more often than not) the non-cumulativeness of pension benefits gained in different member states. These are significant but not necessarily unsurpassable barriers to the achievement of some form of post-national citizenship in the EU. And inasmuch as free movement rights are associated with welfare rights that are insensitive to nationality, they foster the transnationalisation of social solidarity in Europe - the potential construction of a fully harmonised if not unitary welfare system. While the process is controversial and contested, it clearly goes a long way from a conception of the EU as a mere network of intergovernmental relationships. If only for this, free movement undermines the intergovernmentalist description of the European Union. The potential of free movement of persons for the deepening of the process of European integration can thus hardly be underestimated. One has only to be reminded that the full right to travel was not established as a constitutional citizenship right in the US before the 1940s, and that when it was, it was taken to be a fundamental step towards the creation of a fully-fledged federal state. 
last. For countries arliament $\therefore$ to vote I of little ights are attlement re of EU

solidated ory. This ze movece of the dence of without st state's Jirective rers (less e years), the host

1 of free slections national s - inacd (more $\mathrm{d}$ in difsurpassizenship ted with transnatruction cocess is Iception If only cription sons for ardly be o travel ; before tal step
The EU enlargements of 2004 and 2007 again put citizenship mobility at the top of the political agenda in Europe. Heated media debates - for example on the possible invasion of 'Polish plumbers' into France - drew big headlines. As in previous enlargements - that is, when Greece (1981), Spain (1986) and Portugal (1986) joined the European Union - the movement rights of the new European citizens were subject to temporary restrictions. Notably, though, Britain, Ireland and Sweden all opened their doors to the new citizens, and saw substantial in-migration. In 2006 and 2007, the mobility restrictions for citizens from the so-called A10 new EU member states (those who joined in 2004) were mostly lifted in all other member states, with the exception of Germany and Austria. These countries, which have had some of the largest numbers of informal migrants from Central and Eastern Europe, announced that they would maintain national measures until April 2009. For workers of the two new member states joining the EU in 2007 - Romania and Bulgaria - only Finland and Sweden among EU15 states granted full mobility rights from the start. But progressive openings took place elsewhere quite rapidly on a piecemeal basis, with eased conditions of access to job permits for workers from these countries. ${ }^{5}$

To sum up, the free movement of persons across national borders within the EU - a key aim of the overall European integration process - has, step by step, become an everyday feature of European economy and society. The two major legal steps in this process were the abolition of restrictions on movement and residence for workers of member states and their families in 1968, and the introduction of EU citizenship in 1992, alongside the less visible but decisive actions of the European Court of Justice. The Court has stood as a bulwark against all attempts to maintain privileges rooted in pre-existing or re-emerging nationality-based pieces of legislation. Migrant 'workers' - as they were called in the ECSC treaty of 1951 - have become EU 'movers', as they are now usually referred to in EU documents.

\section{ECONOMIC AND POLITICAL RATIONALES FOR FREEDOM OF MOVEMENT}

As we have seen, free movement represents a constant and quintessential concern of the European Union. But why has the EU (and its earlier incarnations) always insisted on promoting free movement? Both economic and political rationales have been advanced. In this section, we review them briefly (see also Recchi 2008).

Generally speaking, in the collective imagery of advocates of European integration, cross-border migration within Europe - whatever its shifting 
political boundaries - is framed and sustained as the sociodemographic counterpart to international trade in an unrestricted single market. Together, a single market and a free movement area would be the triggers of an 'ever closer Union'. In this respect, the project of European integration anticipates the globalisation of the last decades of the 20th century. Indeed, it might be said that the EU constitutes a world-regional variant of globalisation (Castells 1998; Favell 2003).

In somewhat more technical terms, economists conceive of intra-EU migration as the labour market complement to monetary union. Workers' mobility is required in an optimally functioning single currency area. Typically, it is said to absorb local economic shocks to employment which might follow from the collapse of production in any particular local or national context. This argument won Robert Mundell (1961) the Nobel prize for economics in 1999, and stands as the major theory-based justification for the continuing support for free movement of market-oriented pundits and policy makers (see also Belassa 1961; Mattli 1999).

Another economic argument has come to the fore more recently: mobility as an 'autarchic' response to demand at the higher end of the labour market. Mobility is particularly productive when it equates with brain circulation. While the free movement doctrine was born of the need to facilitate working-class migration from the south in the 1950s, in the last decade or so it has been re-focused on encouraging the knowledge economy through a more efficient use of the educated and highly skilled workforce. The ambition is to promote an increased use of European human capital within Europe as a means to 'make the EU the world's most dynamic and competitive economy', as stated in the EU's Lisbon Agenda of 2000. This would especially require the expansion of supranational research and development structures in both the public and private sectors, as part of the global struggle for competitiveness (see Sapir et al. 2004).

From a political viewpoint, on the other hand, free movement is frequently perceived as an instrument to deepen European integration at the societal level. The Action Plan for Skills and Mobility (European Commission 2002) makes it clear that individuals who have tasted free movement rights are expected to better appreciate European citizenship and endorse European unification more wholeheartedly than the rest of the population. This point is taken up again by the most recent legislation consolidating and expanding free movement rights:

Enjoyment of permanent residence by Union citizens who have chosen to settle long term in the host member state would strengthen the feeling of Union citizenship and is a key element in promoting social cohesion, which is one of the fundamental objectives of the Union. (Directive 2004/38)

In 0

diffe

Hav

Hav

The the: anc in $\mathrm{r}$ itse (on this Eur 
ographic market. z triggers 1 integracentury. 1 variant

ntra-EU Norkers' cy area. nt which local or Ie Nobel :d justifioriented

$y:$ mobile labour rain cirto faciliit decade conomy rkforce. I capital mic and 00. This ch and part of

is fretion at ropean ed free renship rest of slation

to settle ion citie of the

In other words, movers are expected to contribute to overcoming national differences, fulfilling the vision of Euro-enthusiast intellectuals like Václav Havel. It evokes also certain cosmopolitan antecedents in Europe, as Havel's commentary makes clear:

If regulations on the movements of citizens disappear, we will see the sort of blending produced in the Austro-Hungarian Monarchy before the First World War. Subjects came and went, married all over the place, tried their luck at many things, without any of the preceding impeding development of national cultures. (Havel 1998, 119)

In this scenario, the fusion of European societies would be greatly facilitated by burgeoning mobility.

Such an emphasis on mobility does not go uncontested. In particular, scholars in the Marxist tradition contend that all efforts to create a 'Europe of flows' (Hajer 2000) are functional to the expansion of capitalism - that is, to the rise of exploitative social relations, the disruption of community life, and negative psychological consequences (for these general arguments, see also Deleuze and Guattari 1980; Harvey 1982; Sennett 1998). The European Year of Workers' Mobility of 2006 thus increasingly sought to focus its efforts on also managing the downsides and social dysfunctions linked to the promotion of mobility. Nonetheless, even critics acknowledge that European integration has become organized around a principle of spatial governance within a frame of 'seamless mobility', with mobility the 'defining feature of contemporary Europe' (Jensen and Richardson 2004, 3).

\section{MOBILE EUROPEANS IN EU STATISTICS}

The next set of questions concerns numbers. How many EU movers are there? Who are they? How are they distributed spatially in terms of origins and destinations? Are their numbers growing? Unfortunately, differences in national systems of registration of residents and freedom of movement itself make it hard to count EU movers in a consistent and systematic way (on these measurement issues, see Poulain et al. 2006). Nevertheless, in this section, we describe our population of reference on the basis of the Eurostat Dissemination Database (EDD), as well as data from the EU Labour Force Survey. The bulk of figures in this section refer to population stocks in EU15 between 1987 and $2004 .^{6}$

Flows have not varied dramatically from the mid-1990s on, but do show a rising trend: from 0.6 million in 1997 to 1.1 million persons in 2003 
(excluding inflows into Greece, France and Ireland). Interestingly, 64 per cent of EU15 movers are returning migrants. Germany, Britain and Spain receive the largest numbers of intra-EU movers yearly. About four out of ten of these movers are in the 25-39 age bracket. British, German, French and Italian citizens (in that order) form the largest nationality groups resettling abroad in the EU.

Regarding stocks, during the period 1987 to 2004, while the overall number of foreign residents grew from 14.4 to 21.4 million $(+48.7$ per cent), the stock of EU movers rose at a slower pace - from about 5.2 to 6.3 million people $(+21.1$ per cent). The number of EU15 non-national residents increased in all member states - particularly in Britain $(+443$ 000), Germany (+207 000) and Spain (+181000) - with the exception of Sweden, France and Italy. In fact, the relative size of EU non-national citizens among foreigners varies considerably from country to country. Intra-EU movers are a majority among foreigners in Luxembourg, Belgium and Ireland. In all other EU member states, there are more nonEuropean immigrants than foreign European residents. There are often three to four times more immigrants than EU movers, and Italy has the lowest proportion of EU movers among its alien residents: only 9.9 per cent.

Since the mid-1980s, Germany, France and Britain have continued to be the countries hosting the largest numbers of EU citizens living abroad. On the other hand, Italians and Portuguese continue to be the largest communities of Europeans residing in another EU member state. However, the size of the Italian and Portuguese communities has oscillated only slightly over these two decades. Interestingly, the fastest growing communities of Europeans abroad are not formed by, southern Europeans - as they were traditionally in the 1950s-1970s - but rather by central and northern Europeans. Between 1987 and 2002, the number of Germans living outside their native country in the EU nearly doubled $(+96$ per cent), while the growth of expatriate French ( +59 per cent), Belgians $(+51$ per cent), British $(+42$ per cent) and Dutch $(+32$ per cent) is also remarkable. Only the Spanish and Finnish communities abroad have shrunk in this period, albeit modestly.

In 1987, the single largest community of EU non-nationals in a EU member state was formed by the Portuguese in France (649 000 persons), where they made up almost half the EU mover population. Their number declined, however, to 555000 persons in 2002. Therefore, in the early 2000 s the single largest community of EU movers is formed by Italians in Germany: 644000 persons, representing 36.6 per cent of EU non-national residents in that country. Their number has increased modestly but constantly from the mid-1980s onwards. This could be due to both continuing

net migratir generation equally accı in Luxembr of geograpl the high pro of Finns in number of of Austriar southern $\mathrm{E}$.

Overall, in another amount to 1.1). Altho prevalence states whe Italy $(65.6$ Portugal (4 six out of People age nationals i cent in Ital

The edu country to a post-secc in Lithuan speaking, like Germ: movers wit per cent re Britain is : have tertia in the higl opportuni differences Portugal, nationals i is true in $\mathrm{F}$

As is $w$ migrants $\mathrm{I}$ ily reflecte demand 1 
y, 64 per nd Spain ur out of , French $\checkmark$ groups

z overall 48.7 per ut 5.2 to national n $(+443$ sption of national country. mbourg, ore nonIre often $r$ has the I 9.9 per led to be oad. On commuever, the I slightly munities as they 1orthern s outside vhile the er cent), ile. Only s period,

in a $\mathrm{EU}$ sersons), number he early alians in national but conntinuing net migration flows from Italy to Germany and the expansion of secondgeneration Italian migrants living in Germany. These same reasons can equally account for the growth in the number of Portuguese citizens living in Luxembourg, which doubled between 1987 and 2002. The importance of geographical and cultural proximity for intra-EU mobility is attested by the high proportion of British citizens in Ireland and of the Irish in Britain, of Finns in Sweden and Swedes in Finland, and Germans in Austria. The number of Austrians in Germany, even though representing 77 per cent of Austrians abroad in the EU, is overshadowed by the larger presence of southern European migrants in Germany.

Overall, including citizens of the accession countries already residing in another EU member state, European citizens living abroad in the EU amount to (only) 1.6 per cent of the EU25 population in 2004 (Table 1.1). Although data on gender are incomplete, apparently there is a slight prevalence of men, with the notable exception of four EU15 member states where women exceed men among EU non-national residents: Italy (65.6 per cent), Greece (59.9 per cent), Ireland (51.6 per cent) and Portugal (51.5 per cent). In 2002, the 25-34 age group was the biggest in six out of the 12 member states for which this information is available. People aged 25 to 44 formed from one-third to half the total of EU nonnationals in each country (ranging from 34 per cent in France to 48 per cent in Italy).

The educational level of intra-EU movers varies considerably from country to country. The proportion of EU15 non-national residents with a post-secondary degree ranges from 11.8 per cent in Spain to 61 per cent in Lithuania (where absolute numbers are very low, though). Generally speaking, traditional receiving countries of intra-European migration, like Germany, Sweden and France, host a less-educated workforce (EU movers with a tertiary-level degree are 14.4 per cent, 22.4 per cent and 25.2 per cent respectively). In this regard, the difference between Germany and Britain is striking, as in the latter country one-third of EU non-nationals have tertiary-level credentials. These individuals are probably taking jobs in the high-skilled sectors, whereas Germany tends to offer employment opportunities to intra-EU movers in mainly low-end occupations. Gender differences also deserve some attention. In Germany, Italy, Spain and Portugal, as well as in all Eastern European countries, among EU15 nonnationals it is men who have higher educational qualifications. The reverse is true in France and Sweden.

As is well known, education is expanding all over the world. But, as migrants represent a select population, this general trend is not necessarily reflected in their educational level. In particular, when labour markets demand low-skilled workers, immigrants tend to be negatively selected 


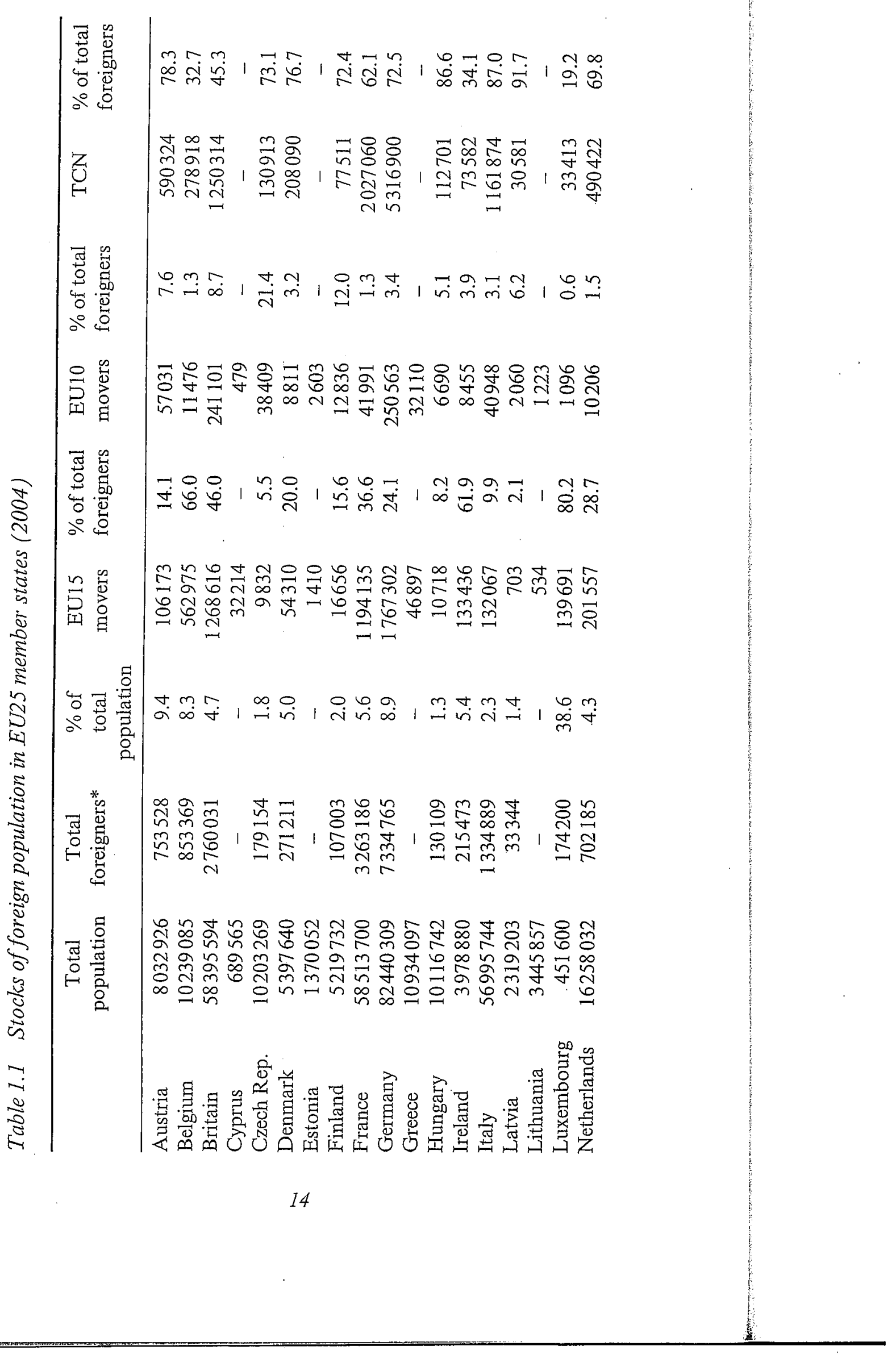




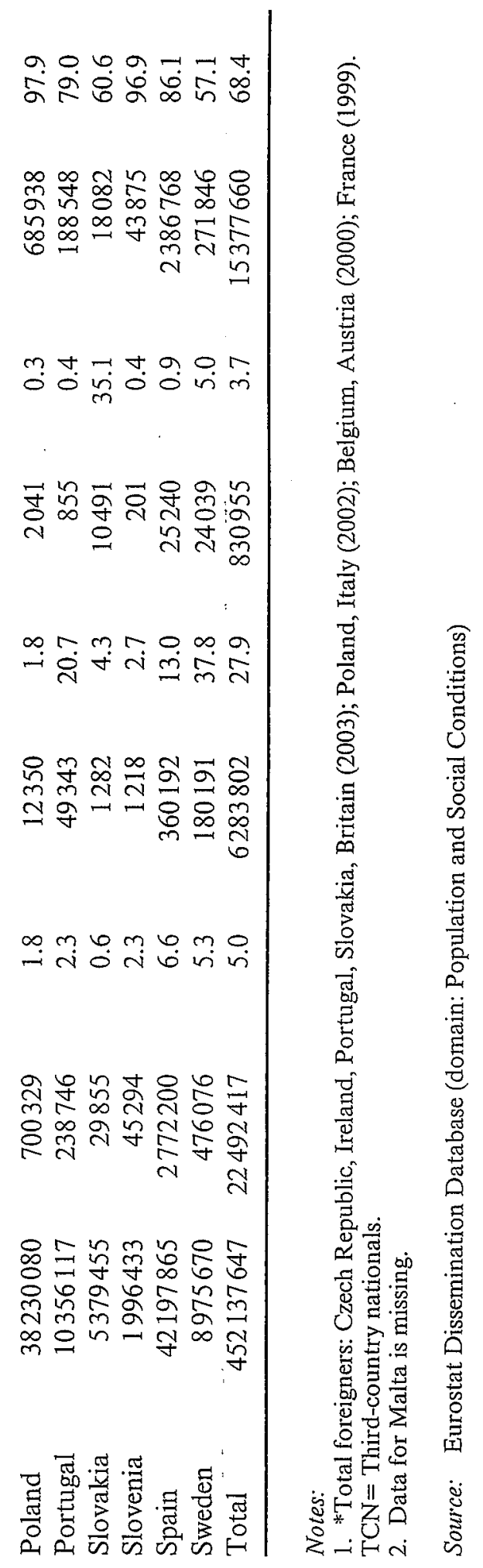


on education (Borjas 1989). Therefore, a diachronic analysis of intra-EU movers' education is informative of the kind of occupational incorporation to which this particular fraction of the migrant population is channelled. Table 1.2 shows that the education of EU non-nationals has improved constantly and markedly from 1995 to 2005 . If in the mid-1990s only 14.3 per cent of intra-EU movers had a tertiary degree, by 2005 this is the case for almost a quarter of them. But the most significant finding is the following: while in 1995 the proportion of national residents with a tertiary-level education was higher than that of EU movers, the situation was reversed in 2005. In other words, the upgrading of the educational level of EU movers has exceeded that of the general population. EU movers are now a positively selected population in terms of education. The education differentials between EU non-nationals and nationals are at their peak in Denmark, Ireland, Luxembourg, Austria, Spain and Portugal. In all these countries, the share of tertiary-educated EU movers is about twice as large as that of nationals. There can be few doubts that geographical mobility within the EU spreads human capital across the labour market, although the size of the population at stake varies considerably from one country to another.

Over time, intra-EU movers are also redefining their position in the workforce (Table 1.3). In terms of sectors of employment, EU citizens living abroad are less likely than nationals and also third-country nationals to have a job in agriculture. More significantly, their involvement in the industrial sector is declining at a faster pace than that of nationals. Indeed, in 1995 the proportion of industrial workers among EU movers was still well above that of nationals ( 55.8 per cent versus 50.9 per cent); after 2000, the two are about the same. Finally, we can distinguish two separate categories in the broad service sector: a low-level sector (mainly including personal service activities) and a mid-high level sector (in which non-manual activities are the rule). In the low-level service sector, EU15 non-nationals are more frequently employed than nationals, but less than third-country nationals. The growth of this sector of employment from the mid-1990s onwards has been almost entirely fed by immigrants from outside the EU. As far as mid-high service jobs are concerned, EU nonnationals are following the path of nationals. Although they still lag behind national workers in relative terms, they are employed in increasingly larger numbers in this more privileged occupational sector.

\section{A GUIDE TO THE VOLUME}

We can now turn to the organisation of the book itself. The volume draws together a number of different analyses by members of the PIONEUR 
intra-EU

cporation

annelled.

improved

only 14.3

; the case

ie follow-

iary-level

versed in

$\mathrm{J}$ movers

$N$ a posi-

ferentials

lenmark,

ountries,

is that of

$n$ the EU

ze of the

r.

in in the

citizens

$r$ nation-

ement in

ationals.

5 movers

er cent);

uish two

(mainly

in which

r, EU15

ess than

snt from

ats from

iU non-

$\mathrm{g}$ behind

ly larger

le draws

JNEUR

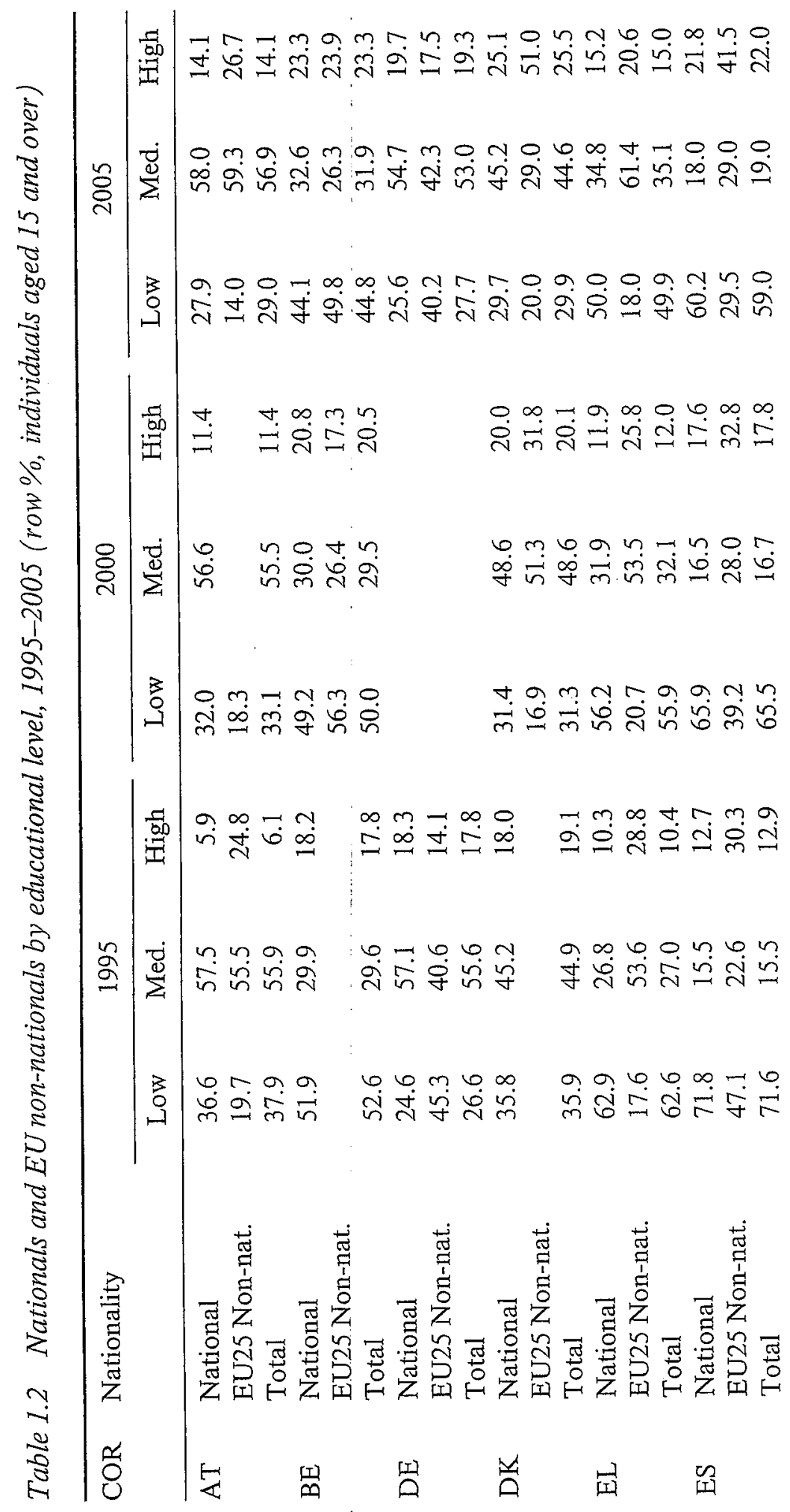




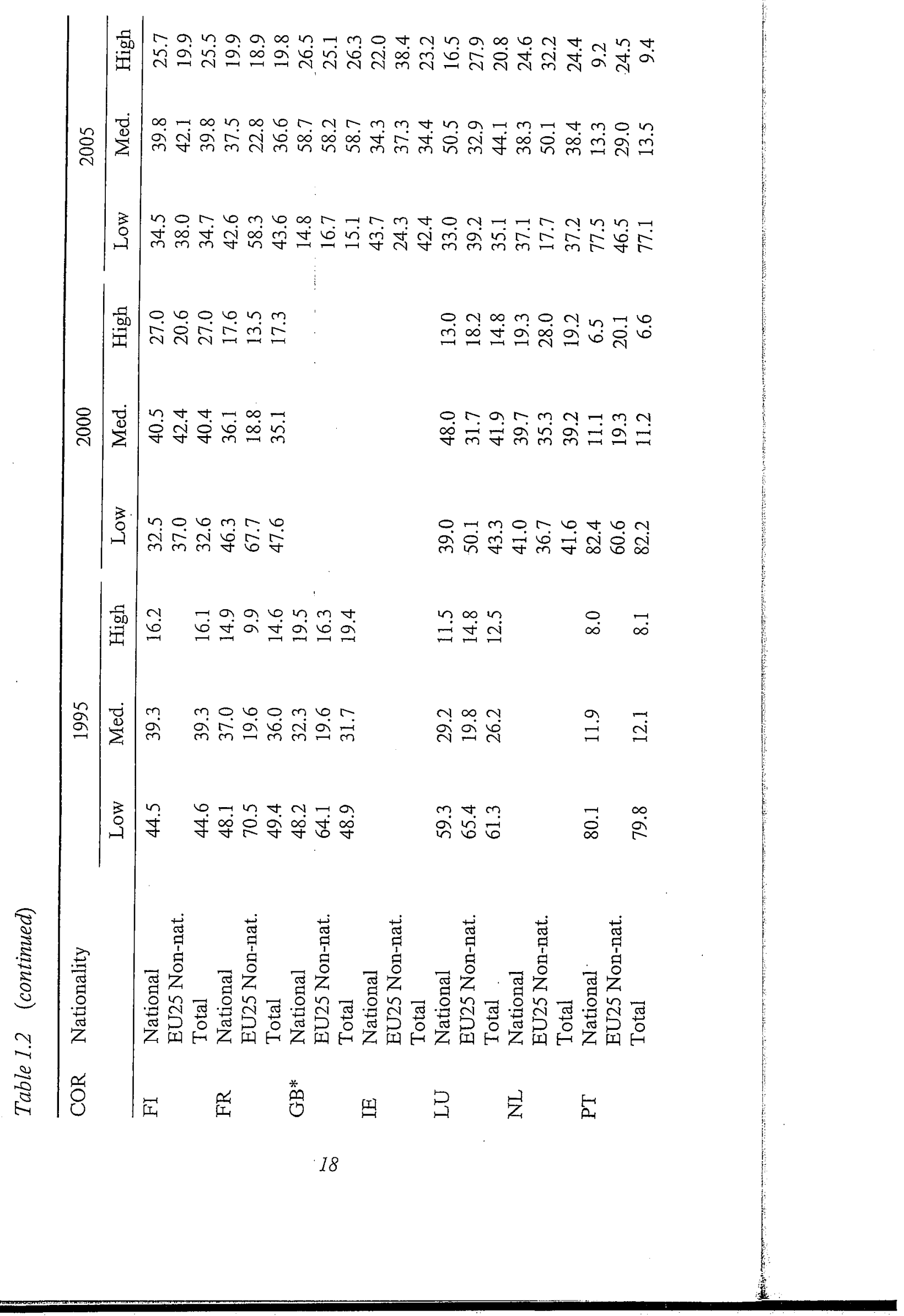




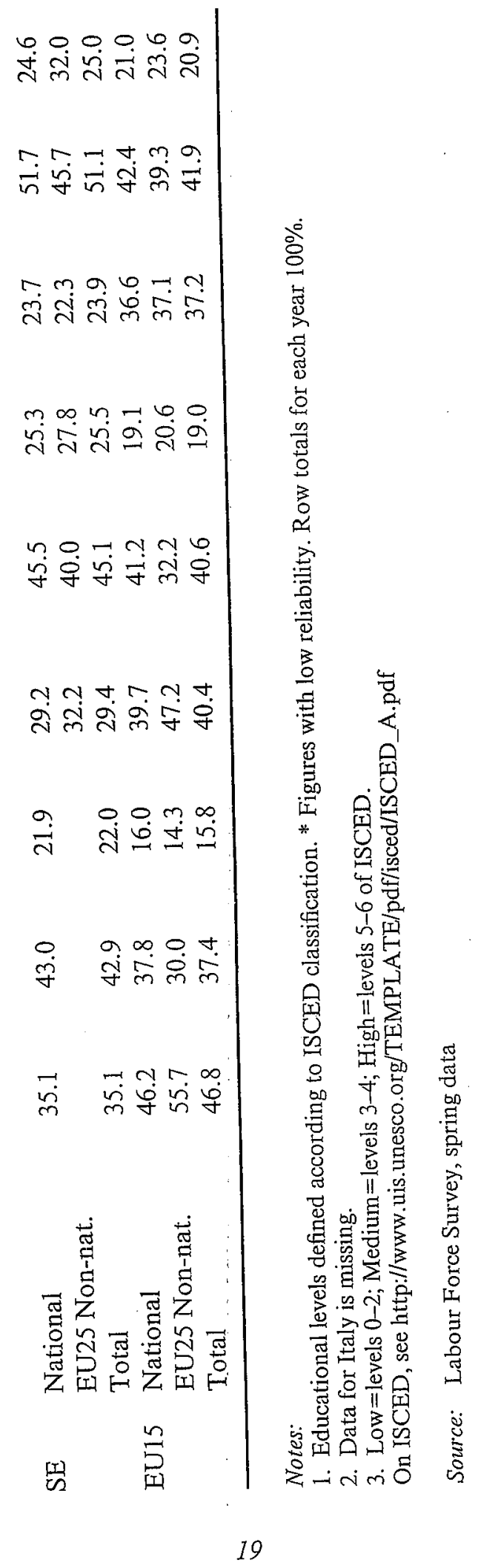


Table 1.3 Employed nationals, EU15 non-nationals and third-country nationals by sector of employment in EU15, 1995-2005 (row $\%$, individuals aged 15 and over)

\begin{tabular}{|c|c|c|c|c|c|c|}
\hline & & Agriculture & Industry & $\begin{array}{c}\text { Service } \\
\text { (low } \\
\text { level) }\end{array}$ & $\begin{array}{c}\text { Service } \\
\text { (mid-high } \\
\text { level) }\end{array}$ & Total \\
\hline \multirow[t]{4}{*}{1995} & Nationals & 5.04 & 50.90 & 9.16 & 34.90 & 100.00 \\
\hline & EU non-nationals & 1.61 & 55.83 & 17.11 & 25.44 & 100.00 \\
\hline & TCN & 1.73 & 60.39 & 14.88 & 23.00 & 100.00 \\
\hline & Total & 4.87 & 51.29 & 9.49 & 34.36 & 100.00 \\
\hline \multirow[t]{4}{*}{2000} & Nationals & 4.31 & 49.17 & 9.51 & 37.01 & 100.00 \\
\hline & EU non-nationals & 1.43 & 49.03 & 18.38 & 31.16 & 100.00 \\
\hline & $\mathrm{TCN}$ & 2.45 & 54.40 & 18.00 & 25.15 & 100.00 \\
\hline & Total & 4.19 & 49.33 & 9.97 & 36.51 & 100.00 \\
\hline \multirow[t]{4}{*}{2005} & Nationals & 3.71 & 46.65 & 9.83 & 39.82 & 100.00 \\
\hline & EU non-nationals & 1.85 & 46.62 & 18.01 & 33.51 & 100.00 \\
\hline & TCN & 3.35 & 48.48 & 23.53 & 24.65 & 100.00 \\
\hline & Total & 3.65 & 46.73 & 10.62 & 39.01 & 100.00 \\
\hline
\end{tabular}

Notes:

NACE activities are grouped as follows:

Agriculture = A. Agriculture, hunting and forestry; B. Fishing.

Industry $=\mathrm{C}$. Mining and quarrying; D. Manufacturing; E. Electricity, gas and water supply; F. Construction; G. Wholesale and retail trade; repair of motor vehicles, motorcycles and personal and household goods; I. Transport, storage and communication. Low level services $=H$. Hotels and restaurants; $O$. Other community, social and personal service activities; P. Private households with employed persons.

Mid-high level services $=\mathrm{J}$. Financial intermediation; $\mathrm{K}$. Real estate, renting and business activities; L. Public administration and defence; compulsory social security; $M$. Education; N. Health and social work; Q. Extra-territorial organizations and bodies. TCN $=$ Third country nationals.

Source: Labour Force Survey, spring data

group, each using the basic EIMSS dataset. Some pose questions in relation to existing European survey sources, such as Eurobarometer (EB) or the European Social Survey (ESS), others derive questions in relation to established studies of migration or immigration. In total, the chapters add up to a comprehensive and unique portrait of the social effects of the EU's extraordinary free movement regime.

Chapter 2 by Michael Braun and Camelia Arsene offers an overview of the mobile population of EU movers surveyed by the EIMSS. Relatively little is known about the population of intra-EU movers, aside from crude figures on stocks and flows in different European countries. First, it details

the social 1 graphic or breaking $c$ migration: emerge: 'l' tion from: north to s are middl and finally and other:

Classic terns of $n$ Intra-EU emergenc space of $t$ Baldoni a intra-EU experienc jective $\mathrm{mc}$ these mor out that ir the lure of is, 'qualit. outweigh also emer cross-nati also featu among ga begins to

In Cha mobility : migrants larly acrc the better to be a ki from per migratior question space ma national s patterns a detailec 
the social background and age of migrants, the duration of migration, geographic origins, and the cross-national marriage patterns of movers. Then, breaking down the population in terms of periods of migration and age at migration, it derives a preliminary typology of EU movers. Four clusters emerge: 'late traditional migrants', continuing the classical labour migration from south to north; 'pure retirement migrants', who are moving from north to south to settle after ending work; 'pre-retirement migrants', who are middle aged, affluent movers who move as part of a lifestyle decision; and finally 'Eurostars', a new highly mobile class of younger professionals and others using European mobility opportunities.

Classic migration theory focuses on the motivation, timing and patterns of migration, and on the social organisation of migration systems. Intra-EU migration can be viewed in these terms, but it also suggests the emergence of new forms of mobility within the evolving transnational space of the European Union. In Chapter 3, Oscar Santacreu, Emiliana Baldoni and Maria-Carmen Albert analyse the complex motivations of intra-EU movers, and the way such migration often builds on successive experiences of mobility within and outside Europe. They focus on the subjective motivations, personal networks and family support that structure these movements, both as separate factors and in combination. It turns out that intra-EU migration is not just driven by economic factors. In fact, the lure of cross-national romance, leisure and lifestyle opportunities (that is, 'quality of life'), and adventure against the new European background outweigh purely economic motivations. Significant gender differences also emerge, especially within the category of 'romance migration', as cross-national partnerships take on specific cross-cultural forms. Sexuality also features in European migration, given higher than average mobility among gays and lesbians. Together with the previous chapter, the analysis begins to draw a new map of migration within Western Europe.

In Chapter 4, Ettore Recchi then tackles the crucial issue of social mobility as it might be related to spatial mobility in the EU. Traditional migrants typically move spatially in order to be mobile socially, particularly across generations. Opportunities for work, education, career and the bettering of lifestyles have, in highly fluid societies, led spatial mobility to be a kind of escalator up the social ladder, often associated with moves from periphery regions to core cities. This has always held for internal migration within European nations, but European integration poses the question of whether spatial mobility within and around the new European space may offer new possibilities to ambitious social climbers on an international scale. EIMSS permits a systematic comparison of social mobility patterns of movers with stayers, using ESS as a reference. Recchi offers a detailed analysis that checks for a number of potential hypotheses of 
inter-generational and intra-generational social mobility. Contrary to some of the hopes associated with European integration, he finds that there is not a substantial structural mobility effect. EU movement opportunities tend to be more used by middle- and upper-class Europeans, and the bulk of movers stay fixed in the same occupational class they belonged to before moving abroad.

A large part of traditional immigration studies focuses on processes of acculturation, assimilation or integration (depending on the model) of immigrants into national host societies, according to a series of indexes regarding language use, cultural adaptation, family life and social practices. EIMSS was set up to enable the evaluation of acculturation processes of foreign resident Europeans in their destination countries, and does so for different countries and different nationalities, across cohorts, gender and social classes. In Chapter 5, Antonio Alaminos and Oscar Santacreu highlight the discrepancies between the social and cultural integration of EU movers, showing that these distinctly transnational migrants in Europe differ substantially from typical immigrants in how they combine the pull of their home culture with the challenges of the new country of residency. Lack of language proficiency proves to be no great barrier to effective integration of migrants in the host society, even though it limits networks that take them out of their own national milieus.

Chapter 6 by Nina Rother and Tina Nebe pushes this line of inquiry deep into the question of European and national identity. Much of the European Commission's justificatory commentary on freedom of movement stresses the positive impact of mobility on the emergence of European identity. Movement is meant to establish a more solid foundation for the EU, through positive, affective identification with the European project. Referring to the large body of data and existing research based on regular Eurobarometer surveys measuring support for European integration, territorial attachment and the hierarchisation of national, local and transnational identity, EIMSS repeats these questions for the EU movers. These individuals might indeed be considered the prototypical 'Highly Europeanized Citizens' (HECs), benefiting the most from the European integration project. Nebe and Rother create a typology of movers on the basis of distinct patterns of identification with country of origin, country of residence and the EU. Elaborating the social psychology literature, they find that one potential for European identity is that it reduces the "cognitive dissonance' felt by movers caught between strong national identifications. A European identity in this way is not incompatible with existing national identities.

In Chapter 7, by Anne Muxel, the big political questions about European citizenship are asked. Much of the literature on European

citizen

partici survey well pl such $\mathrm{c}$ rates a compe The cl politic and st open ] suppo backg than $\mathrm{r}$

A $\mathrm{f}$

Eurof literat cussin integr comm is alsc conte: media Rothe

Euror televis more of $\mathrm{CO}$ of $10 c$ under ity an attem

Fin ing of ing a : took what May in-de] labou sion tions 
rary to

ids that

oppor-

ns, and

slonged

esses of

del) of

indexes

1 prac-

I proc-

id does

gender

itacreu

rration

ints in

mbine

itry of

rier to

limits

Iquiry

of the

move-

opean

or the

oject.

zgular

ation,

tran-

Jvers.

lighly

spean

$n$ the

untry

, they

ogni-

ifica-

sting

bout

pean citizenship has focused on the opportunities European nationals have to participate as EU citizens abroad in local and European elections. Our survey took place at the time of the 2004 European elections, and so was well placed to gauge this participation amongst a representative sample of such citizens. As expected, movers do participate more than stayers, but rates are not impressive. It is necessary, therefore, to go beyond voting and compare the importance of this to other forms of political involvement. The chapter also analyses data for the first time available on the left/right political orientation of EU movers and their attitudes on liberalisation and state intervention. These prototypical beneficiaries of a more liberal, open European market, paradoxically tend at the same time to be more supportive of state intervention. A closer look shows that the social class background and education of EU movers matter more to participation than national differences.

A further essential area of inquiry on the question of an emergent European transnational space is, of course, the media. A large body of literature on migration and media studies has emerged in recent years discussing the possibilities of transnational media in the context of European integration and beyond, and of new diaspora media and new channels of communication associated with innovative technologies. Europe however is also characterized by a very weak public sphere beyond nation-state contexts, given the modest success of attempts to create print or visual media for a European market. Chapter 8 by Damian Tambini and Nina Rother shows that EU movers are consumers of transnational and European media where available, and they show a strikingly low use of television media compared to print media and the internet. However, a more accurate classification would see their media consumption in terms of combinatory approaches that also often involve appreciation and use of local (host country) media alongside international sources. They also underline that emerging transnational patterns are linked to the availability and quality of media in different countries, findings that are relevant to attempts to construct a more effective European media space.

Finally, in Chapter 9, Adrian Favell and Tina Nebe push the questioning of PIONEUR out into the effects of EU enlargement. As well as offering a systematic survey of West European intra-EU migration, PIONEUR took up the challenge of comparing findings on intra-EU migration with what might be expected from new member states which joined the EU in May 2004 and which were about to join in 2007. A series of 40 qualitative in-depth interviews were thus conducted with 'higher' and 'lower' end labour migrants from both Poland and Romania (the two largest accession countries) in the five selected Western member states. Similar questions to EIMSS were posed, bearing in mind that the features of intra-EU 
migration - borderless mobility, no technical barriers, minimal prejudice - are certainly not a given for movers from any East-Central European country. The life stories of these new pioneers in fact speak more to a traditional immigrant experience. They face discrimination and barriers not apparent to Western EU movers, while also seeing Western Europe as a place to advance career aspirations or opportunities for their children. The chapter points towards new research on the future of the regional migration system in Europe, as East-West migration comes to more resemble the intra-EU migration within Western Europe surveyed by EIMSS.

\section{CONCLUDING REMARKS:}

The study of European integration has been slow to incorporate sociological analyses. Pioneers of European Integration represents a key empirical contribution to an emerging sociology and human geography of the European Union (for an overview of existing contributions see Bettin Lattes and Recchi 2005; Favell and Guiraudon 2010). Migration and mobility have long been recognized as important dimensions of the European project, but systematic empirical studies have been scarce. Some studies have tackled dimensions of this new mobility (King et al. 2000; Favell 2008a), and there has been much reflection on the significance of European citizenship (Magnette 1999; Bellamy et al. 2006) and European identity (Hermann et al. 2004; Checkel and Katzenstein 2009; Fligstein 2008). It is the first time, however, that systematic, representative data on spatial mobility and its social effects within and across Western Europe have been presented and analysed in this form.

Europe is unfinished but the freedom of movement of persons has wrought dramatic social change. Much of this is not yet fully visible. Some of the most dramatic examples can be found in the lives and experiences of those who took up most enthusiastically their new rights of European citizenship, and decided to give it a go living and working in another member state. Successful movement and resettlement is far from a given. But, as we show in this book, Europe will never be the same again: neither for the EU movers, nor for those stayers now getting used to their foreign neighbours as colleagues, friends and partners. The pioneers of European integration are also, perhaps, the pioneers of a better, brighter Europe for all. 
srejudice iuropean to a trariers not ope as a ren. The il migraresemble SS.

ate socis a. key ography :ions see Ligration is of the ce. Some al. 2000 ; cance of ,uropean Fligstein : data on เ Europe sons has le. Some iences of sean citimember ut, as we $r$ the EU ighbours egration

\section{NOTES}

1. The claim is based on data from Eurobarometer 64.1 of 2005 . The question is: "Which of the following statements best describe(s) what the European Union means to you personally?' It was also asked in 1997, 1998 and 2001.

2. Figures for mobile students and researchers are taken from European Commission reports, available via: http://ec.europa.eu/education/index_en.htm.

3. See the PIONEUR website: http://www.obets.ua.es/pioneur/.

4. In most original random large-scale surveys - such as the Labour Force Surveys - the number of migrants surveyed is usually a very small percentage of the overall population. EIMSS differed by devising a names-based telephone methodology for identifying migrants - who are a very small part of the overall population - in sufficient numbers. Our survey is comparable to ones made in Israel and Australia, among the few countries where different immigrant groups can be identified in sufficient numbers to survey comparatively (see Appendix A for more details).

5. An overview of the issue and the changing national measures can be found on the EC website: http://ec.europa.eu/social/main.jsp?catid=466\&langid=en?/free_movement/enlargement_en.htn.

6. Data and tables presented in this section are taken from Recchi et al. (2006), which also contains more fine-tuned analyses. 